\title{
The Effect of Vitamin E Supplements Added to Clomiphene Citrate Treatment on Fertility in Polycystic Ovary Syndrome
}

\section{Polikistik over sendromunda Klomifen Sitrat Tedavisine Eklenen E Vitamini Takviyelerinin Fertilite Üzerine Etkisi}

\author{
Derya Kanza Gül ${ }^{1 *}$, Ayça Şolt Kırca ${ }^{2}$ \\ ${ }^{1}$ Medipol University School of Medicine Health, Istanbul, Turkey, Turkey. \\ ${ }^{2}$ Kirklareli University School of Health, Midwifery Depertmant, Kirklareli, Turkey. \\ e-mail: deryakanza@yahoo.com, aycasolt@hotmail.com \\ ORCID: 0000-0001-8879-9299 \\ ORCID: 0000-0001-6733-5348 \\ *Sorumlu yazar/ Corresponding Author: Derya Kanza Gül \\ Gönderim Tarihi / Received: 19.12.2020 \\ Kabul Tarihi / Accepted: 06.03.2021 \\ DOI: $10.34087 /$ cbusbed. 843323

\section{Öz}

Giriş ve Amaç: Bu çalışma, infertil Polikistik Over Sendromu (PKOS) olan kadınlarda klomifen sitrat (KS) ile ovulasyon indüksiyonunda sikluslar sırasında E vitamini desteğinin ovülasyon defekti, endometrium kalınlığg, klinik ve devam eden gebelik artışı üzerindeki rolünü araştırmak için tasarlanmıştır.

Gereç ve Yöntemler: Bu retrospektif vaka kontrol çalışmasında, 1 Ocak 2015 ile 1 Ekim 2020 tarihleri arasında Yenibosna Özel Nisa Hastanesi Kadın Hastalıkları Kliniğine infertilite tedavisi için başvuran PKOS hastaları değerlendirildi. KS ve vitamin E tedavisi alan (Vitamin E grubu) PKOS'lu 139 hasta ve sadece KS tedavisi alan 167 PKOS hastası (Kontrol grubu) olmak üzere toplam 306 hasta değerlendirildi. Birincil sonuç, kümülatif yumurtlama oranının (yani, tüm takip süresi boyunca yumurtlamanın meydana geldiği döngülerin oranı), ikincil sonucun dominant folikül sayısı, HCG'ye uygulama gününde endometriyal kalınlık ve klinik ve devam eden gebelik oranlarıdır.

Bulgular: İki grup arasında dominant folikül sayıları, ovulasyon oranları, klinik ve devam eden gebelik oranları açısından istatistiksel fark saptanmadı ( $>>0.05)$. E vitamini grubu ile kontrol grubu karşılaştırıldığında endometrial kalınlık açısından gruplar arasında istatistiksel olarak anlamlı fark olduğu belirlendi $(\mathrm{p}<0.000)$.

Sonuç: Sikluslar sırasında verilen E vitamini desteğinin PKOS'lu infertil kadınlarda dominant folikül sayısını, ovulasyon oranlarını ve klinik ve devam eden gebelik oranlarını artırmada etkili olmadığı, ancak endometrial kalınlık artışına neden olduğu bulundu.

Anahtar kelimeler: E vitamini, Kısırlık, Klomifen sitrat, Polikistik over sendromu.

\footnotetext{
Abstract

Objective: This study was designed to investigate the role of vitamin E supplementation during cycles in ovulation induction with clomiphene citrate (CC) in women with infertile Polycystic Ovary Syndrome (PCOS) on ovulation defect, endometrium thickness, clinical and ongoing pregnancy increase.

Materials and Methods: In this retrospective case control study, PCOS patients admitting to Yenibosna Private Nisa Hospital Obstetrics Clinic between January $1^{\text {st }} 2015$ and October $1^{\text {st }} 2020$ for infertility treatment were evaluated. A total of 306 patients were evaluated, including 139 Patients with PCOS receiving CC and vitamin E treatment (Vitamin E group), and 167 patients with PCOS who received CC treatment only (Clomiphene group). The primary result was that the cumulative ovulation rate (i.e. the rate of the cycles in which ovulation occurs during the entire follow-up period), the secondary result was the number of dominant follicles, the endometrial thickness on the day of HCG admission, and the clinical and ongoing pregnancy rates.

Results: No statistical differences were detected between the two groups in terms of dominant follicle counts, ovulation rates, and clinical and ongoing pregnancy rates $(\mathrm{p}>0.05)$. When the vitamin E group and control group were compared it was determined that there was a statistically significant difference between the groups in terms of endometrial thickness $(\mathrm{p}<0.000)$.
} 
Conclusion: It was found that vitamin E supplementation given during the cycles was not effective in increasing the number of dominant follicles, ovulation rates, and clinical and ongoing pregnancy rates in infertile women with PCOS, but increased endometrial thickness.

Keywords: Clomiphene citrate, Infertility, Polycystic ovary syndrome, Vitamin E.

\begin{abstract}
1. Introduction
Polycystic Ovary Syndrome (PCOS) was first described by Stein and Leventhal in 1935, having a prevalence of $10 \%$ in women of reproductive age[1]. asone of the most common causes of oligo-anovulation infertility[2].Clinically, PCOS has four main features as; (1) polycystic ovaries, (2) hyperandrogenism, (3) clinical features of hyperandrogenism, and (4) ovulation and menstrual dysfunction. Obesity has cardiovascular risk factors like insulin resistance, metabolic syndrome, dyslipidemia, and the presence of endothelial dysfunction [1]. PCOS is a heterogeneous disease with multifactorial etiology like the genetics, environmental factors, and oxidative stress. Oxidative stress, which is defined as the imbalance between pro- and anti-oxidants, was considered to play key roles in the development of PCOS[3]. The most important mechanism initiating oxidative stress in PCOS is insulin resistance and hyperandrogenism[4,5]. The imbalance in follicular fluid environment with increased Oxidative Stress (OS) causes poor oocyte development, embryo development, and pregnancy, which result in miscarriage[6].
\end{abstract}

Vitamin E ( $\alpha$-tocopherol) is a non-enzymatic andoilsoluble antioxidant molecule, and was first found by Evans and Bishop in 1922 [7]. Vitamin E inhibits phospholipase A and lipoxygenase activity to stabilize cell membrane, regulatethe oxidative stress, and antioxidant imbalance, regulating the normal physiological function of reproduction [8]. Vitamin E deficiency can cause infertility in women, miscarriage, premature birth, eclampsia, fetal intrauterine growth restriction and other pregnancy-related diseases $[9,10]$ Vitamin E might reduce the senile oxidative stress reaction, which can have a harmful effect on the number and quality of oocytes [11]. Several animal and human studies reported that the use of vitamin $\mathrm{E}$ at a dose of 400 - $1000 \mathrm{mg} /$ day in infertile patients might be beneficial in increasing the implantation and pregnancy rates by improving in vitro maturation rates, blastocyst ratesand oocyte rates $[12,13]$.

Clomiphene Citrate (CC) is a primary treatment option tostimulate ovulation in women with PCOS seeking pregnancy, and shows its effect by preventing the negative feedback cycle mediating the estrogen in the hypothalamus[14]. Due to the CC'santiestrogenic effect on hypothalamus, hypophysis and uterus, it was found to affect endometrial thickness and implantation ratesnegatively [15]. This study was designed to investigate the role of vitamin $\mathrm{E}$ supplementation on ovulation, endometrium thickness, and clinical pregnancy increasesin frequency in ovulation induction with $\mathrm{CC}$ in infertile women with PCOS, which is a common ovulation defect in the society.

\section{Materials ve Methods}

The Clinical Research Ethics Committee of Istanbul Medipol University approved the study. The management of Private Nisa Hospital where the study was to be conducted gave its written permission to conduct the study before the data collection phase. (Reference number: 10840098-772.02-E.61617 Date: 17/11/2020).

In this retrospective case control study, the data obtained with the hospital file and computer registration system scanned to investigate the role of vitamin $\mathrm{E}$ in ovulation, endometrium thickness increase, and clinical pregnancy increases in ovulation induction of women with PCOS applying for infertility treatment to Yenibosna Private Nisa Hospital Obstetrics Clinic between January 1, 2015 and October 1, 2020.

The diagnosis of PCOS is made to women who meet at least two-thirds of the Rotterdam Criteria (Rotterdam ESHRE/ASRM-sponsored 2006): 1)Oligomenorrhea or amenorrhea, 2)Clinical or biochemical symptom of hyperandrogenism, 3)Polycystic ovaries in ultrasonography: the presence of 12 or more follicles ranging in diameter from 2 to $9 \mathrm{~mm}$ in transvaginal ultrasound screening, or ovary volume increase more than $10 \mathrm{~cm} 3[16]$.

The patients who were under the age of 40 , treated with CC and/or vitamin E admitting to our clinic with anovulatory infertility due to PCOS constituted the criteria for inclusion in our study. Exclusion criteria were male factor infertility, Tubal factor infertility (abnormal hysterosalpingography), hyperprolactinemia, hypothyroid, hyperthyroid, hypertension, kidney and liver disease, smoking and alcohol use, being antidiabetic, using anti-obesity drugs, and insulin use.

A total of 306 patients were evaluated in this study, including 139 patients with $\mathrm{CC}$ and $\mathrm{E}$ vitamin treatment who met the inclusion and exclusion criteria, and 167 patients with PCOS and who received CC therapy only were included as the Clomiphane group.

The demographic and clinical data of the patients were obtained by using the patient files and hospital database. Two different protocols are applied in our hospital in ovulation induction in patients with PCOS treated for anovulation and infertility. In the first protocol, CC (Klomen:Kocak pharmaceutical, Turkey) treatment is applied as only $150 \mathrm{mg} /$ day for 5 days starting from the 3rdday of menstruation. In the second protocol, vitamin $\mathrm{E}$ is added to $400 \mathrm{mg}$ capsule treatment for 28 days starting from the 1st day of menstruation in addition to the CC treatment (Evicap fort:Kocak pharmaceuticals, Turkey). The number of dominant follicles $(\geq 18 \mathrm{~mm})$ and endometrial thickness are evaluated with transvaginal ultrasonography on the 12thand 14thdays of the cycles. When at least one dominant follicle is detected, 250 micrograms $/ 0.5 \mathrm{~mL}$ (equivalent to $6500 \mathrm{lU}$ ) of chorionic gonadotropin alpha subcutaneously (Ovitrelle: Merck 
Serono, Italy). Ovulation is evaluated with ultrasonography (i.e. corpus luteum). Couples are instructed to have scheduled sexual intercourse 36 hours after the alpha injection of chorionic gonadotropin. Serum HCG is determined for pregnancy diagnosis 15 days after alpha injection of chorionic gonadotropin without menstruation. In patients without dominant follicles, a new ovulation induction process is started the following month. Patients are given training on the expected side effects of vitamin $\mathrm{E}$.

The primary result is the cumulative ovulation rate (i.e. the rate of the cycles in which ovulation occurs in the follow-up period), the secondary result is the number of dominant follicles, the endometrial thickness on the day of HCG admission, and the clinical and ongoing pregnancy rate.

Statistical Analysis

The SPSS 22.0 Software Program was used in the analysis of the study data. Shapiro-Wilk Test was used to examine whether the distribution of variables was normal in this study. The Student $t$ test was used to compare the normally-distributed data by groups, and the MannWhitney U-test was used to compare the data that did not show normal distribution by groups. The results of the analysis were given as mean, deviation, median, minimum and maximum values for the quantitative data. The $p$ value of less than .05 was accepted as statistically significant.

\section{Results and Discussion}

3.1.Results

As seen in Table 1, it was found that the study groups had similar characteristics in terms of age, height, weight, Body Mass Index (BMI) values and infertility durations (p>.05, Table 1). It was also found that the groups were homogeneous in terms of FSH, LH, Estradiol, TSH and prolactin values, and $>18 \mathrm{~mm}$ dominant follicle count (p>.05). When the groups were compared by taking and not taking vitamin $\mathrm{E}$, it was determined that there were statistically significant differences between the groups in terms of endometrial thickness $(\mathrm{p}<0.05)$.

It was found in the study that the groups had similar characteristics in terms of ovulation, clinical pregnancy, ongoing pregnancy, previous-ovarium, count and previous live birth count characteristics among the groups ( $>.05$, Table 2). A total of $43.2 \%(n=60)$ of vitamin $\mathrm{E}$ group had ovulation and $49.7 \% \quad(\mathrm{n}=83)$ ovulation occurred in the group that did not take vitamin E. Clinical pregnancies were determined in $8.6 \%(n=12)$ and $8.4 \%(n=14)$ in groups who were taking and not taking vitamin $\mathrm{E}$. The continued status of pregnancy was $7.2 \%(n=10)$ and $7.6 \%(n=12)$ in the groups who were taking and not taking vitamin E. In the group who was taking vitamin $\mathrm{E}$, the number of ovarium stimuli was $51.1 \%$, and it was found to be $49.7 \%$ in the group that did not take vitamin $\mathrm{E}$

Table 1. The comparison of the groups in terms of demographic, clinical and hormonal status

\begin{tabular}{|l|c|c|c|}
\hline & $\begin{array}{c}\text { Vitamin E group } \\
(\mathbf{n = 1 3 9 )} \\
\text { Mean } \pm \text { sd }\end{array}$ & $\begin{array}{c}\text { Clomiphane group } \\
(\mathbf{n = 1 6 7}) \\
\text { Mean } \pm \text { sd }\end{array}$ & P \\
\hline Age (years) & $31.29 \pm 5.2$ & $30.91 \pm 5.9$ & $0.547^{*}$ \\
\hline Height(cm) & $162.3 \pm 4.42$ & $162.6 \pm 4.03$ & 0.435 \\
\hline Weight(kg) & $65.53 \pm 5.83$ & $66.48 \pm 4.59$ & 0.062 \\
\hline BMI(kg/m2) & $28.25 \pm 2.08$ & $27.1 \pm 2.03$ & 0.101 \\
\hline Duration of Infertility (years) & $2.10 \pm 0.81$ & $1.97 \pm 0.71$ & 0.144 \\
\hline FSH(mIU/mL) & $6.73 \pm 2.03$ & $6.99 \pm 1.65$ & $0.09^{* *}$ \\
\hline LH(mIU/mL) & $14.30 \pm 2.23$ & $14.03 \pm 1.88$ & 0.181 \\
\hline Estradiol & $48.09 \pm 7.39$ & $47.57 \pm 7.54$ & 0.675 \\
\hline Prolactin(ng/mL) & $16.93 \pm 4.29$ & $17.29 \pm 2.96$ & 0.068 \\
\hline TSH(mIU/mL) & $1.83 \pm 0.62$ & $2.00 \pm 0.52$ & $0.063^{* *}$ \\
\hline No. of dominant follicles $(\geq 18 \mathrm{~mm})$ & $1.00 \pm 0.80$ & $1.10 \pm 0.69$ & 0.071 \\
\hline Endometrial thickness(mm) & $10.69 \pm 1.43$ & $7.47 \pm 2.19$ & $\mathbf{0 . 0 0 0}$ \\
\hline \hline
\end{tabular}

*Mann-Whitney U Test, ${ }^{* *}$ Student $t$ test. BMI: Body Mass Index, LH: luteinizing hormone, FSH: folliclestimulating hormone, TSH: troid stimulating hormone. 
Table 2. The clinical outcomes of PCOS women in ovulation induction with or without vitamin E

\begin{tabular}{|c|c|c|c|c|c|}
\hline & Vitan & & Clom & roup & p \\
\hline & n & $\%$ & n & $\%$ & \\
\hline $\begin{array}{l}\text { Ovulation } \\
\text { Yes } \\
\text { No }\end{array}$ & $\begin{array}{l}60 \\
79\end{array}$ & $\begin{array}{l}43.2 \\
56.8\end{array}$ & $\begin{array}{l}83 \\
84\end{array}$ & $\begin{array}{l}49.7 \\
50.3\end{array}$ & $0.254^{* *}$ \\
\hline $\begin{array}{l}\text { Clinical pregnancy } \\
\text { Yes } \\
\text { No }\end{array}$ & $\begin{array}{c}12 \\
127\end{array}$ & $\begin{array}{c}8.6 \\
91.4\end{array}$ & $\begin{array}{c}14 \\
153\end{array}$ & $\begin{array}{c}8.4 \\
91.6\end{array}$ & $0.938^{* *}$ \\
\hline $\begin{array}{l}\text { Ongoing pregnancy } \\
\text { Yes } \\
\text { No }\end{array}$ & $\begin{array}{c}10 \\
129\end{array}$ & $\begin{array}{l}7.2 \\
92.8\end{array}$ & $\begin{array}{c}11 \\
156\end{array}$ & $\begin{array}{l}6.6 \\
93.4\end{array}$ & $0.834^{* *}$ \\
\hline $\begin{array}{l}\text { Menstrual cycles } \\
\text { Oligomenorrhea } \\
\text { Amenore } \\
\text { Regular }\end{array}$ & $\begin{array}{l}90 \\
29 \\
20\end{array}$ & $\begin{array}{l}64.7 \\
20.9 \\
14.4\end{array}$ & $\begin{array}{l}64 \\
37 \\
66\end{array}$ & $\begin{array}{l}38.3 \\
22.2 \\
39.5\end{array}$ & $0.000^{* *}$ \\
\hline $\begin{array}{l}\text { Previous ovarian stimuli count } \\
0 \text { count } \\
1 \text { count }\end{array}$ & $\begin{array}{l}71 \\
68\end{array}$ & $\begin{array}{l}51.1 \\
48.9\end{array}$ & $\begin{array}{l}83 \\
84\end{array}$ & $\begin{array}{l}49.7 \\
50.3\end{array}$ & $0.811^{*}$ \\
\hline $\begin{array}{l}\text { Previous live birth count } \\
0 \\
1\end{array}$ & $\begin{array}{c}114 \\
25\end{array}$ & $\begin{array}{l}82 \\
18\end{array}$ & $\begin{array}{c}125 \\
42\end{array}$ & $\begin{array}{l}74.9 \\
25.1\end{array}$ & $0.132 *$ \\
\hline
\end{tabular}

**Chi-Square Test, *Mann-Whitney U Test

The previous number of live births was $18 \%$ in the group taking vitamin $\mathrm{E}$, and $25.1 \%$ in the group that did not take vitamin $\mathrm{E}$. When the groups were examined in terms of menstrual status, it was determined that there were differences between the groups $(\mathrm{p}<.05$, Table 2). Oligomenorrhea was $64.7 \%$ in the group taking vitamin $\mathrm{E}$, and $38.3 \%$ in the group that did not take vitamin $\mathrm{E}$ (Table 2).

\subsection{Discussion}

In this study, vitamin E supplementation added to $\mathrm{CC}$ during ovulation induction was not effective in increasing the number of dominant follicles, ovulation rates, clinical and ongoing pregnancy rates in infertile women with PCOS. However, it was found that the increase in endometrial thickness, which is important in implantation and in the continuity of pregnancy, was more common in patients who used vitamin E. The fact that the study groups had similar characteristics in terms of the findings that negatively affected fertility (i.e. age, height, weight, Body Mass Index (BMI) values, FSH, LH, Estradiol, TSH and prolactin values and infertility duration) makes the study results more significant.

PCOS is one of the most common causes of oligoanovulatory infertility in women in reproductive period [2]. The most important reason of PCOS-related infertility was that there were high oxidative stress levels defined as an imbalance between pro- and anti-oxidants [3]. Antioxidants play major roles as intercell and intracell messengers in the ovarium, providing communication between ovarian tension and stromal cells. They have serious importance for ovulation, and can increase the rate of pregnancy [17]. A systematic review showed that serum and follicular antioxidant levels were associated with better oocyte quality and maturation. The imbalance in the follicular fluid environment because of increased oxidative stress (OS) in PCOS mightcause poor oocyte development, embryo development, and pregnancy, which result in miscarriage [6].

Insulin resistance and hyperandrogenemia are the most important mechanisms initiating oxidative stress in PCOS [4]. When the literature was reviewed, numerous studies were detected emphasizing that vitamin E can positively affect reproductive physiology by protecting the ovary from reactive oxygen species during luteolysis. Its use with vitamin $\mathrm{E}$ and Omega-3 was found to have beneficial effects on total antioxidant capacity, malondialdehyde concentrations, glutathione levels, and catalases activity [18]. In their study conducted by Izadi et al. in patients with PCOS, they found that serum total testosterone levels decreased when compared to the placebo group and significantly improved sex hormone binding globulin (SHBG) levels in patients who receive vitamin E and CoQ10 (Coenzyme Q)[19]. Also, CoQ10 reduces the Visceral Adiposity Index (VAI) values in women with vitamin E PCOS, and increase the cardiac protective effects as well as lowering insulin resistance [20]. Another study reported that the supplementation of magnesium and vitamin E for 12 weeks mightbring benefits for women with PCOS in hirsutism, serum hsCRP, plasma NO (Nitric oxide), and Total Antioxidant Capacity (TAC) levels [21]. 
When the effects of vitamin E supplementation on clinical pregnancy success in infertile women with PCOS and ovulation induction were examined, different results were detected in the literature. In their study conducted with 200 patients that had PCOS, Panti et al. found that antioxidant treatment (e.g. Vitamin A, C, D, zinc and copper) increased clinical pregnancy rates at statistically significant levels[22]. In a meta-analysis that analyzed 28 randomized controlled trials, which included a total of 3548 women,it was found that antioxidants were not associated with the increase in live birth rates or in clinical pregnancy rates[23]. Fatemi et al. reported that D and $\mathrm{E}$ vitamin supplementation increased pregnancy ratesin 105 women with PCOS who underwent infertile intrastoplasmic insemination (ICSI) in different nonantioxidant ways[13].

It was found in Chen et al.'s study conducted on 321 infertile women with PCOS that short-term vitamin E supplementation in follicular phase reduced oxidative stress and exogenous HMG dosage, might reduce the malondialdehyde (MDA) and oxidative stress serum markers on the day of HCG administration, increase total antioxidant capacity measurements (TAC), endometrium thickness and E2 levels, but did not change the pregnancy rates[24]. It was seen that CC, which is frequently used in patients with PCOS, negatively affectedthe endometrial thickness and implantation rateswith its antiestrogenic effects on the hypothalamus, pituitary and uterus [15].For this reason, additional treatments are required that increase endometrial thickness for CC. For this reason, vitamin $\mathrm{E}$ treatment is promising. In their study conductedon $90 \mathrm{CC}$ resistant women with PCOS,Morsy et al. found that the addition of vitamin E to $\mathrm{CC}$ did not affect the number of dominant follicles, ovulation rates, midluteal progesterone level, and pregnancy rates; however, positively affected the increase in endometrial thickness, which played important roles in implantation [25].Çiçek et al. found that the application of vitamin $\mathrm{E}$ improved endometrial response in infertile women whoseinfertility could notbe explained with possible antioxidant and anticoagulant effects [26].In another study, it was detected that vitamin E supplement applied for 12 weeks had beneficial effects on endometrial thickness, MDA values, and LDLR, IL-1 (interleukin 1), and TNF- $\alpha$ (tumor-necrotizing factor alpha) gene expression [27].Similarly, in this study, no differences were detected in terms of $>18 \mathrm{~mm}$ dominant follicle count, ovulation, and pregnancy rates in the group that received vitamin $\mathrm{E}$ but endometrial thickness was more.

The present study is one of the few studies that investigate the effects of vitamin $\mathrm{E}$ treatmentapplied during cycleson ovulation and pregnancy success in women with PCOS receivingCCtreatment. The small size of the sampling, and the lack of power calculation are the internal limitations of this study. Also, the use of a retrospective design, and the data obtained from a thirdline hospital limited the generalization of results to general population.

\section{Conclusion}

As a conclusion, vitamin E supplementation, which is given in addition to $\mathrm{CC}$ used in cycles as an ovulation induction, was not found to be effective in increasing the number of dominant follicles, ovulation rate, and clinical and ongoing pregnancy rate in infertile women with PCOS. Prospective studies are needed with large number of participants to investigate the benefits of vitamin $E$ on fertility by neutralizing the endometrium-thinning effect of $\mathrm{CC}$, which increases endometrial thickness.

\section{Acknowledgements and Disclosures}

The authors have no conflicts of interest to declare. No funding received.

\section{References}

1. Goodarzi, M.O, Dumestic, D.A, Chazenbalk, G, Azziz, R, Polycystic ovary syndrome; etiology, pathogenesis and diagnosis, Nature Reviews Endocrinology, 2011, 7, 219-31.

2.Joham, A.E, Teede, H.J, Ronasinha, S, Zanges, S, Boyle, J, Prevalence of infertility and use of fertility treatment in women with polycystic ovary syndrome; data from a large community based study, Journal of Women Health, 2015, 24(4), 299-307.

3. Kurdoglu, Z, Ozkol, H, Tuluce, Y, Koyuncu, I, Oxidative status and its relation with insulin resistance in young non-obese women with polycystic ovary syndrome, Journal of Endocrinoogy Investigation, 2012, 35(3), 317-21.

4. Victor, V.M, Rucha, M, Banuls, C, Alvarez, A, De- Pablo, C, SachezSsrrano, M, et al., Induction of oxidative stress and human leukocyte/endothelial cell interactions in polycystic ovary syndrome patients with insulin resistance, Journal of Clinical Endocrinology and Metabolism, 2011, 96(10), 3115-22.

5. Muni, M, Luque-Mirez, M, Insenser, M, Ojede-Ojede, M, EscobarMorreds, H.F, Circulating markers of oxidative stress and polycystic ovary syndrome; a systemic review and meta-analysis, Human Reproduction Update, 2013, 19(3), 268-88.

6. Miyamoto, K, Sato, E.F, Kasahare, E, Jikumaru, M, Hiramoto, K, Tabate, $\mathrm{H}$, et al., Effect of oxidative stress during repeated ovulation on the structure and function of the ovary, oocyte and the mitochondria, Free Radical Biology and Medicine, 2010, 49(4), 67481.

7.Evans, H.M, Bishop, K.S, On the existence of a hitherto unrecognized dietary factor essential for reproduction, Science, 1922, 56(1458), 650-1.

8. Traber, M.G, Atkinson, J, Vitamin E, antioxidant and nothing more, Free Radical Biology and Medicine, 2007, 43, 4-15.

9. Wahid, S, Khan, R.A, Feroz, Z, Reduction in mortality and teratogenicity following simultaneous administration of folic acid and vitamin $\mathrm{E}$ with antiepileptic, antihypertensive and anti-allergic drugs, Journal of Pharmacy Bioallied Science, 2014, 6(3), 185-91.

10. Hubalek, M, Buchner, H, Mortl, M.G, Schlembach, D, Huppertz, B, Firulovic, B, Kohler, W, Hafner, E, Dieplinger, B, Wildt, L, et al., The vitamin E-binding protein afamin increases in maternal serum during pregnancy, Clinica Chimica Acta, 2014, 434, 41-7.

11. Tarin, J.J, Perez-Albala, S, Cano, A, Oral antioxidants counteract the negative effects of female aging on oocyte quantity and quality in the Mouse, Moleculer Reproduction and Development, 2002, 61(3), 385-97.

12. Farzollahi, M, Tayefi-Nasrabadi, H, Mohammadnejad, D, Abedelahi, A, Supplementation of culture media with vitamin E improves mouse antral follicle maturation and embryo development from vitrified ovarian tissue, Journal of Obstetrics Gynaecology Research, 2016, 42(5), 526-35.

13. Fatemi, F, Mohammadzadeh, A, Sadeghi, M.R, Akhondi, M.M, Mohammadmoradi, S, Kamali, K, Lackpour, N, Jouhari, S, Zafadoust, S, Mokhtar, S, et al., Role of vitamin E and D3 supplementation in intra-cytoplasmic sperm injection outcomes of women with polycystic ovarian syndrome: a double blinded randomized placebo-controlled trial, Clinical Nutrution ESPEN, 2017, 18, 23-30.

14. Bjelica, A, Trninić-Pjević, A, Mladenović-Segedi, L, Cetković, N, Petrović, D Comparison of the efficiency of clomiphene citrate 
and letrozole in combination with metformin in moderately obese clomiphene citrate-resistant polycystic ovarian syndrome patients, Srpski Arhiv Za Celokupno Lekarstvo, 2016, 144(3-4), 146-50.

15. Gerli, S, Gholami, H, Manna, C, Di Frega, A.S, Vitiello, C, Unfer, V, Use of ethinyl estradiol to reverse the antiestrogenic effects of clomiphene citrate in patients undergoing intrauterine insemination: A comparative, randomized study, Fertility and Sterility, 2000, 73, 85-89.

16. Rotterdam ESHRE/ASRM-sponsored PCOS consensus workshop group. Revised 2003, Consensus on diagnostic criteria and long-term health risk related to polycystic ovary syndrome (PCOS), Human Reproduction, 2004, 19(1), 41-7.

17. Rosselli, M, Keller, R, Dubey, R.K. Role of nitric oxide in the biology, physiology and pathophysiology of reproduction, Human Reprod uction Update, 1998, 4, 3-24.

18. Sadeghi, F, Alavi-Naeini, A, Mardanian, F, Ghazvini, M.R, Mahaki B, Omega-3 and vitamin E co-supplementation can improve antioxidant markers in obese/overweight women with polycystic ovary syndrome, International Journal for Vitamin and Nutrition Research, 2020, 90(5-6), 477-483.

19. Izadi, A, Ebrahimi, S, Shirazi, S, Taghizadeh, S, Parizad, M, Farzadi, L, Gargari, BP, Hormonal and Metabolic Effects of Coenzyme Q10 and/or Vitamin E in Patients With Polycystic Ovary Syndrome..Journal of Clinical Endocrinology Metabolism, 2019, 104(2), 319-327.

20. Izadi, A, Shirazi, S, Taghizadeh, S, Gargari, B.P, Independent and Additive Effects of Coenzyme Q10 and Vitamin E on Cardiometabolic Outcomes and Visceral Adiposity in Women With Polycystic Ovary Syndrome, Archives of Medical Research, 2019, 50(2), 1-10.

21. Shokrpour, M, Asemi, Z, The Effects of Magnesium and Vitamin E Co Supplementation on Hormonal Status and Biomarkers of Inflammation and Oxidative Stress in Women with Polycystic Ovary Syndrome, Biological Trace Element Research, 2019, 191(1), 54-60.

22. Panti, A, Shehu, C, Saidu, Y, Tunau, K, Nwobodo, E, Jimoh, et al, Oxidative stress and outcome of antioxidant supplementation in patients with polycystic ovarian syndrome (PCOS) International Journal of Reproduction, Contraception, Obstetrics and Gynecology, 2018, 7(5), 1667-1672.

23. Showell, M.G, Mackenzie-Proctor, R, Jordan, V, Hart, R.J, Antioxidants for female subfertility, Cochrane Database Systemical Review, 2017, 7, CD007807.

24. Chen J, Guo Q, Pei Y, Ren Q, Chi L, Hu R and Tan Y Effect of a short-term vitamin $\mathrm{E}$ supplementation on oxidative stress in infertile PCOS women under ovulation induction: a retrospective cohort study BMC Women's Health. 2020,20:69,1-9.

25. Morsy, A, Sabri, N, Mourad, A, Mojahed, E, and Shawki, M, Randomized controlled open-label study of the effect of vitamin E supplementation on fertility in clomiphene citrate-resistant polycystic ovary syndrome, Journal of Obstetrics and Gynaecology Research, 2020, 1-8.

26. Cicek, N, Eryilmaz, O.G, Sarikaya, E, Gulerman, C, Genc, Y, Vitamin E effect on controlled ovarian stimulation of unexplained infertile women, The Journal of Assisted Reproduction and Genetics, 2012, 29(4), 325-8

27. Hashemi, ZSN, Khani, B, The effects of vitamin E supplementation on endometrial thickness, and gene expression of vascula endothelial growth factor and inflammatory cytokines among women with implantation failure, Journal of Maternal Fetal Neonatal Medine, 2017, 32(3), 1-19.

http://edergi.cbu.edu.tr/ojs/index.php/cbusbed isimli yazarın CBU-SBED başlıklı eseri bu Creative Commons Alıntı-Gayriticari4.0 Uluslararası Lisansı ile lisanslanmıştır.

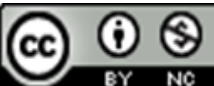

